\title{
Challenges in utilisation of small family norm
}

\author{
Varuna Pathak $^{1 *}$, Madhuri Chandra², Veena Rathi Bisani ${ }^{1}$
}

\begin{abstract}
${ }^{1}$ Department of Obstetrics and Gynaecology, Gandhi Medical College, Bhopal, Madhya Pradesh, India
${ }^{2}$ Department of Obstetrics and Gynaecology, Mahavir Institute of Medical Sciences, Bhopal, India
\end{abstract}

Received: 16 November 2016

Revised: 22 November 2016

Accepted: 03 December 2016

\section{*Correspondence:}

Dr. Varuna Pathak,

E-mail: drvarunapathak@gmail.com

Copyright: (C) the author(s), publisher and licensee Medip Academy. This is an open-access article distributed under the terms of the Creative Commons Attribution Non-Commercial License, which permits unrestricted non-commercial use, distribution, and reproduction in any medium, provided the original work is properly cited.

\section{ABSTRACT}

Background: India is the most populous country in the world, sustaining $17.5 \%$ of the world's population on $2.4 \%$ of the world's surface area. Despite of India being the first country to formulate a National Family Planning Programme in 1952, the population of India continues to rise. Therefore a basic question arises, as to why do couple have a third child? For stabilization of population every couple must on an average have 2.2 children, but how far our family planning programmes having an impact on the beneficiaries, in terms of their ideologies and utilisation of the programme. To get answers to the above question the present study was undertaken with the following aims and objectives to determine the views about ideal family size and ideal spacing, to determine the degree of knowledge about various contraceptive methods, to know the family size amongst population not adopting small family norm and to know the reason for non-acceptance of family planning methods.

Methods: This was a hospital based case control study. Cases were women with two live children and not practicing family planning. Controls included women who opted for family planning methods and adopted the two child norm. Both cases and controls were asked to fill up a questionnaire.

Results: Most people practicing small family norm view ideal number of issues $\leq 2$ i.e. $88 \%$ of males and $91 \%$ of females. $59.8 \%$ couples not practicing family planning, think ideal spacing $\leq 2$ years. $100 \%$ controls had the concept of contraception.

Conclusions: Desire for a male child in $30.6 \%$ cases is the most common reason for couples not following the 2 child norm.

Keywords: Hospital based, India, Questionnaire, Small family

\section{INTRODUCTION}

India with $1,340,529,871$ (1.34billion) people is the second most populous country in the world, while China is on the top with over 1,415,489,506(1.41 billion) people. Census 2011 shows that India represents almost $17.5 \%$ of the world's population which means one out of six people on this planet live in India. ${ }^{1}$

Currently there are about 51 births in India in a minute. This, despite that India was the first country to launch the National Family Planning Programme in 1952. The National Family Population Policy 2000 had set goal that the country would have to achieve the replacement level of fertility by 2010, but India failed to achieve any of the goals and at this rate we would grow from 1210 million in 2011 to 1400 million in 2026 and become the most populous country of the world by $2030 .^{2}$ It was presumed in the National programmes that access to information or counselling and services for fertility regulation and contraception, with a wide basket of contraception choices would help people limit their family size with proper spacing.

However, it should be recognised that while the practice of contraception is spreading among the more intelligent and civilised individual, the more backward ones are 
reproducing without restriction. Those who need to use contraception in the interest of the community are the ones who are least likely to use it.

The NPP-2000 document clearly stated that the population growth in India continues to be high on account of demographic momentum (estimated contribution $58 \%$ ), higher wanted fertility rate due to high infant mortality rate (estimated contribution of 20\%) and a higher fertility due to unmet need for contraception (estimated contribution of about 20\%). ${ }^{3}$ Thus, we cannot be oblivious to the inbuilt demographic momentum in India's population because younger age structure is expected to contribute around $60 \%$ to the expected population growth. Furthermore $20 \%$ of the growth potential is attributed to higher wanted fertility and $20 \%$ to unwanted fertility because of the higher unmet need of contraception. According to Kulkarni $\mathrm{S}$ the unmet need of contraception because of definitional deficiencies and measurement errors has been debated in the past. ${ }^{4}$ In an attempt to fill the gap in the programmes providing birth control approaches and the actual utilisation of these by population to restrict their family size. The present study was conducted in an attempt to answer one basic question that why do couples have a third child with the following aims and objectives.

1. To determine the views about family size and ideal spacing.
2. To determine the degree of knowledge about various contraceptive methods.

3. To know the family size amongst population not adopting small family norm.

4. To know the reason for non-acceptance of family planning methods.

\section{METHODS}

This was a hospital based case control study. Cases were women with two living children not practising family planning. Controls included women who opted for family planning methods and adopted the two child norm. Both cases and controls were asked to fill up a questionnaire which included questions like age, education status, religion, occupation, monthly income, type of family setup, nuclear/joint, obstetric history, knowledge about family planning methods, previous use of any contraceptive, reason for non-acceptance of small family norm, views on ideal spacing.

\section{RESULTS}

Most people practicing small family norm view ideal number of issues $\leq 2$ i.e. $88 \%$ of males and $91 \%$ of females. $59.8 \%$ couples not practicing family planning, think ideal spacing $\leq 2$ years. $100 \%$ controls had the concept of contraception.

Table 1: Views on ideal family size.

\begin{tabular}{|c|c|c|c|c|c|c|c|c|}
\hline \multirow[t]{3}{*}{ Ideal family size } & \multicolumn{4}{|c|}{ Husband } & \multicolumn{4}{|l|}{ Wife } \\
\hline & \multicolumn{2}{|l|}{ Cases } & \multicolumn{2}{|l|}{ Controls } & \multicolumn{2}{|l|}{ Cases } & \multicolumn{2}{|l|}{ Controls } \\
\hline & Number & $\%$ & Number & $\%$ & Number & $\%$ & Number & $\%$ \\
\hline 01 & 3 & 0.6 & 00 & 00 & 3 & 0.6 & 10 & 2 \\
\hline 02 & 170 & 14.6 & 440 & 88 & 179 & 35.8 & 445 & 89 \\
\hline 03 & 289 & 57.8 & 55 & 11 & 275 & 55 & 40 & 8 \\
\hline 04 & 34 & 6.8 & 05 & 01 & 35 & 7 & 5 & 1 \\
\hline 05 & 2 & 0.4 & 00 & 00 & 4 & 0.8 & 0 & 0 \\
\hline 06 & 22 & 0.4 & 00 & 00 & 3 & 0.6 & 0 & 0 \\
\hline Total & 500 & 100 & 500 & 100 & 500 & 100 & 500 & 100 \\
\hline
\end{tabular}

Table 2: Views on ideal spacing.

\begin{tabular}{|c|c|c|c|c|c|c|c|c|}
\hline \multirow[t]{3}{*}{ Spacing (yrs) } & \multicolumn{4}{|c|}{ Husband } & \multicolumn{4}{|l|}{ Wife } \\
\hline & \multicolumn{2}{|l|}{ Cases } & \multicolumn{2}{|l|}{ Controls } & \multicolumn{2}{|l|}{ Cases } & \multicolumn{2}{|l|}{ Controls } \\
\hline & Number & $\%$ & Number & $\%$ & Number & $\%$ & Number & $\%$ \\
\hline 1 & 30 & 6 & 10 & 2 & 30 & 6 & 10 & 2 \\
\hline 2 & 269 & 53.8 & 100 & 20 & 269 & 53.8 & 100 & 20 \\
\hline 3 & 191 & 38.2 & 285 & 57 & 189 & 37.9 & 280 & 56 \\
\hline 4 & 10 & 2 & 60 & 12 & 11 & 2.2 & 55 & 11 \\
\hline 5 & 0 & 0 & 80 & 18 & 1 & 0.1 & 50 & 10 \\
\hline No idea & 0 & 0 & 5 & 1 & 0 & 0 & 5 & 1 \\
\hline Total & 500 & 100 & 500 & 100 & 500 & 100 & 500 & 100 \\
\hline
\end{tabular}


Table 3: Knowledge of contraception.

\begin{tabular}{|lllll|}
\hline Contraceptives & Cases & \multicolumn{3}{c|}{ Controls } \\
\hline & Number & $\%$ & Number & $\%$ \\
\hline $\begin{array}{l}\text { Having } \\
\text { knowledge of } \\
\text { contraception }\end{array}$ & 446 & 89.2 & 500 & 100 \\
\hline $\begin{array}{l}\text { Having no } \\
\text { knowledge of } \\
\text { contraception }\end{array}$ & 54 & 10.8 & 0 & 0 \\
\hline Total & 500 & 100 & 500 & 100 \\
\hline
\end{tabular}

Table 4: Family size among clients not following small family norm.

\begin{tabular}{|lll|}
\hline Live children & Cases & \\
\hline & Number & $\%$ \\
\hline 2 & - & - \\
\hline 3 & - & - \\
\hline 4 & 269 & 53.8 \\
\hline 5 & 160 & 32 \\
\hline 6 & 53 & 10.6 \\
\hline 7 & 14 & 2.8 \\
\hline Total & 4 & 0.8 \\
\hline
\end{tabular}

Table 5: Reason for non-acceptance of small family norm.

\begin{tabular}{|llll|}
\hline 1 & $\begin{array}{l}\text { Reason for non-acceptance } \\
\text { No knowledge of any }\end{array}$ & 21 & 4.2 \\
\hline 2 & Nothod & & \\
\hline 3 & Desire for male child & 153 & 30.6 \\
\hline 4 & Desire for female child & 60 & 12 \\
\hline 5 & Methods considered harmful & 30 & 6 \\
\hline 6 & $\begin{array}{l}\text { Methods considered } \\
\text { unreliable }\end{array}$ & 23 & 4.6 \\
\hline 7 & Objection by spouse & 48 & 9.6 \\
\hline 8 & $\begin{array}{l}\text { Considered against } \\
\text { religion/customs at family }\end{array}$ & 38 & 7.6 \\
\hline 9 & God's will & 20 & 4 \\
\hline 10 & $\begin{array}{l}\text { Social myths } \\
\text { Conceived by } \\
\text { mistake/Failure of method }\end{array}$ & 63 & 7.6 \\
\hline 12 & $\begin{array}{l}\text { Previous child } \\
\text { handicapped/mentally } \\
\text { retarded }\end{array}$ & 3 & 0.6 \\
\hline & Total & 500 & 100 \\
\hline
\end{tabular}

\section{DISCUSSION}

At the national level, the use of contraception increased from $10 \%$ of couples effectively protected in 1970 to over $45 \%$ in 2000. According to NFHS 3 the wanted fertility rate for India as a whole is 1.9 and the general awareness of contraception is almost universal (98\% among women and $98.6 \%$ among men). ${ }^{5}$ The overall performance of the official family planning program has averted around 257 million births until 2000. ${ }^{6}$ Both NFHS and DLHS showed that contraceptive use is generally rising. Contraceptive use among married women (15-49 years was 56.3\% in NHFS 3(an increase of 8.1 points from NHFS 2)while corresponding increase between DLHS 2 and 3 is relatively lesser(from $52.5 \%$ to $54 \%)$

As per the report submitted by Kulkarni $S$ et al it appears that the gap between the reproductive intentions of couples and their contraception behaviour is responsible for increased family size. ${ }^{4}$ Conceptually the non-use of contraceptives by couples despite their desire of not having a child temporarily or permanently is being termed as the unmet need of contraception. Awareness of contraceptive method is knowledge of where these methods can be obtained, what are the main side effects are and how to use the selected method correctly. Incomplete or erroneous information on where to obtain methods and how to use them is strongly associated with unmet need. The total unmet need for family planning among currently married women between 15-49 years is $12.1 \%$ in both NHFS 3 and $4.5,7$

The present study reveals that $88 \%$ of males and $91 \%$ females believed that the ideal family size should be of two or less children, however the presence of at least one living male child in their family tends to bias their opinion as they consider that at least one male child in the family is essential. As also by NFHS -3 in MP, $31 \%$ of women and $28 \%$ men want more sons. ${ }^{5}$ NHFS data of married women with two children if both are males shows that $92.1 \%$ of them do not want any more children, if they have one son and one daughter, $89.7 \%$ do not want any more children, but if both are daughters $62.2 \%$ desire another child. NHFS 4 published by International Institute of population services Mumbai shows that sex ratio of total population has dropped to 948 in NHFS 4 as against 961 in NHFS $3 .^{5,7}$ The child sex ratio (CSR) for the age group of 0-6 years as per the 2011 census has dipped further to 918 as against 927 per thousand boys as recorded in 2001 census. $^{1}$ In a study on son preference in India the authors concluded that son preference was most pronounced among mothers of north urban sample. In yet another study, the authors concluded that "independent of socioeconomic factors, women with more sons have a lower desire to have another child and are more likely to use contraception than those with more daughters". 8,9

$56-57 \%$ clients of the control group consider 3 years as ideal spacing, while $59.8 \%$ of study group consider ideal spacing $\leq 2$ years. NFHS-3 shows the median interval between births in MP is 29 months, $67 \%$ of non-first order births occur within 3 years of previous births, including $12 \%$ of births that take place within 18 months of last birth and $18 \%$ of births between 18-23 months. ${ }^{5}$ The NHFS 4 shows that the unmet need for spacing in MP is $5.7 \%$, unmet need for family planning is $12.1 \%$ 
and the total unmet need is $21.6 \% .^{7}$ Infact the unmet need has declined in all states of India except Madhya Pradesh where it has remained static according to the same source.

Studies show that if the current unmet need for family planning could be fulfilled over the next 5 years, we can avert 35,000 maternal deaths, 1.2 million infant deaths, save more than Rs 4450 crores and save Rs 6,500 crores, if safe abortion services are coupled with increased family planning services.

Funding: No funding sources Conflict of interest: None declared

Ethical approval: Not required

\section{REFERENCES}

1. Census of India. Government of India, Ministry of Home affairs, Office of the Registrar General and Census Commissioner, India. 2011.

2. National Commission on Population. Ministry of Health and Family Welfare, Government of India. 2011.

3. Government of India. National Population Policy2000, Department of Family Welfare, Government of India. 2000.
4. Kulkarni S, Jayachandran AA. Unmet need for Family Planning -analysis of NHFS Data for selected states of India in eds K. Srinivasan et al. Population Development Nexus in India: Challenges for the New Millennium. Tata McGraw- Hill Publishing Co. Ltd, New Delhi; 2001.

5. National Family Health Survey-3. Ministry of Health and Family Welfare, Government of India. 2005-6.

6. Family welfare program in India year book. Department of family welfare ministry of health and family welfare Government of India. 2001.

7. National Family Health Survey-4. Ministry of Health and Family Welfare, Government of India, State fact Sheet, Madhya Pradesh. 2015-16.

8. Klaus D, Tipandjan A. Son preference in India: Shedding light on North South gradient. Comparative population studies. 2015;40(1):77-102.

9. Jayaraman A, Mishra V. The Effect of Family size and Composition on Fertility Desires, Contraceptive adoption and method choice in South Asia, Demographic and Health Research, DHS working papers. 2008;40:5-23.

Cite this article as: Pathak V, Chandra M, Bisani VR. Challenges in utilisation of small family norm. Int J Reprod Contracept Obstet Gynecol 2017;6:2769. 